\title{
Reproductive characteristics of a free-ranging population of Cape mountain zebra (Equus zebra zebra)
}

\author{
B. L. Penzhorn \\ Department of Genesiology, Faculty of Veterinary Science, University of Pretoria, P.O. Box 12580, \\ Onderstepoort 0110, Republic of South Africa
}

\begin{abstract}
Summary. In a population of free-ranging Cape mountain zebra, median age at first foaling was 67 months (range 38-105 months), median foaling interval was 25 months (range 13-69 months) and annual foaling rate was $32 \%$. Foaling rates of younger and older mares were similar. Foals were born all year round with a peak corresponding to the rainy season (summer). Conception occurred later in the season when the spring was dry.
\end{abstract}

\section{Introduction}

The members of the free-ranging population of Cape mountain zebra (Equus zebra zebra) in the Mountain Zebra National Park (MZNP) are individually known. Records of reproductive performance of each mare can therefore be kept. Reproductive data of free-ranging equid populations may be useful for comparison with breeding of domestic horses (E. caballus). Despite intensive management, mean conception rates of domestic horse mares are $60-70 \%$, with a foaling rate (live foal at 6 weeks) of about $60 \%$ (Rowlands, 1981). There are indications that breeding regimens which closely approximate the situation in free-living equids may give the best results (van Rensburg \& van Heerden, 1953; Belonje, 1956; Bristol, 1982). Conversely, the ecology of freeranging populations with low reproductive rates might offer clues to the identification of limiting factors.

The MZNP is situated near Cradock in the Midland Division, Cape Province, Republic of South Africa $\left(32^{\circ} 15^{\prime} \mathrm{S}, 25^{\circ} 41^{\prime} \mathrm{E}\right)$. The initial population had died out by 1950 , when 11 mountain zebras were donated to the MZNP by a neighbouring farmer. The first foal was born in February 1953 and records of foaling dates have been kept since then. In 1964 the MZNP was enlarged to $65.36 \mathrm{~km}^{2}(6536 \mathrm{ha})$ and the purchase of 30 Cape mountain zebras on one of the farms increased the population in the MZNP to 55. The records of 16 subsequent foaling seasons were analysed to ascertain possible correlation between precipitation and the foaling season. Monthly distribution of births, age at first foaling, foaling interval and minimum age at last foal were also determined. Annual foaling rate, based on records of reproductive success of individual mares, could also be calculated. Surviving foals only could be recorded and the figures mentioned here therefore represent minimum values.

\section{Materials and Methods}

The characteristic stripe patterns of zebras facilitate individual recognition even in quite large populations (Penzhorn, 1984a). All the zebras in the MZNP population could be recognized in the field with the aid of photographs. Records we the composition of each herd and the births of foals were noted. The birth dates of were known fairly accurately. Herds which

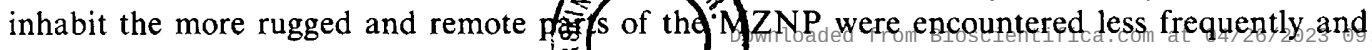


months sometimes elapsed between sightings. The approximate age of a foal and hence its month of birth could be estimated by comparing its size relative to its dam (Penzhorn, 1982a). Reproductive records of individual mares have been kept since 1971 and data up to the $1981 / 82$ foaling season are included here. Ages of foals at foot in 1971 were estimated, extending the records of reproductive performance of some mares to 12 or 13 foaling seasons. The foaling season in which a mare turned 3 years old was regarded as the first in which foaling could be expected.

A foaling season was defined as the period 1 July to 30 June the following year. This includes the austral summer, which was defined as the 6-month period from October to March when the mean maximum temperature exceeded $20^{\circ} \mathrm{C}$ and $72 \%$ of the annual precipitation occurred. Winter was defined as the 6-month period from April to September when the mean maximum temperature was below $20^{\circ} \mathrm{C}$ and only $28 \%$ of the annual precipitation occurred. Snowfalls occurred 3-5 times each winter. Precipitation was measured at the MZNP headquarters in a standard rain-gauge supplied by the Weather Bureau. Mean monthly precipitation over 20 years (1 July 1962-30 June 1982) was calculated.

\section{Results}

All values stated here are based on observation only, and therefore probably underestimate the actual figures for the MZNP population.

\section{Reproductive lifespan}

Cape mountain zebra mares in the MZNP were recorded as foaling for the first time at a median age of 67 months (range 38-105 months) (Text-fig. 1). The gestation period of Cape mountain zebras has not been determined, but is assumed to be about 12 months. A mare running with a feral donkey ( $E$. asinus) stallion gave birth to a hybrid foal 374 days after capture (Penzhorn, 1984a). The duration of pregnancy of a domestic horse mare in foal to a donkey stallion is some 15 days longer than if she is mated to a horse (Hammond, Mason \& Robinson, 1971). If the same applies to mountain zebras, the normal gestation period would be $\geqslant 359$ days. In conspecific Hartmann zebras (E. zebra hartmannae) a gestation period of 364 days has been reported (Joubert, 1974) and a foaling interval of 375 days was observed in a captive mare (Penzhorn, 1975). Therefore, the Cape mountain zebra mare foaling at 38 months probably conceived at about 26 months of age.

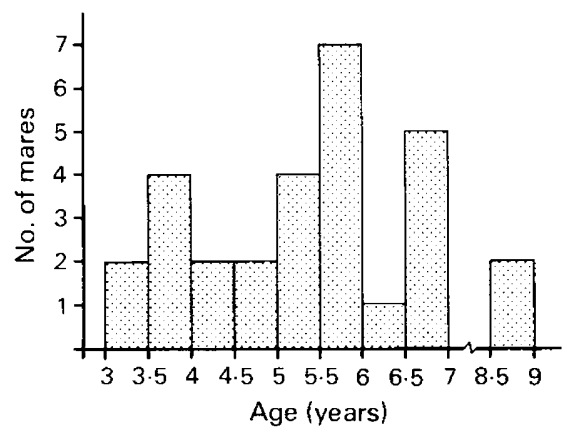

Text-fig. 1. The age at first foaling of 29 Cape mountain zebra mares in the Mountain Zebra National Park (median 67 months).

The minimum ages at which 3 old mares had their last foals were known. One was $\geqslant 17$ years old. The second was $\geqslant 19$ years old and lived a further 5 years. The third was $\geqslant 21$ years old and lived a further $2 \cdot 5$ years. 


\section{Reproductive performance}

The foaling intervals of 49 Cape mountain zebra mares, some foaling up to 6 times during the study period, were recorded. The median foaling interval was 25 months (range 13-69 months) (Text-fig. 2). The foaling intervals of mares known to be 13 years and older were compared to those of younger mares. The difference was insignificant (Wilcoxon's signed-rank test, $Z=-1 \cdot 2028$ ).

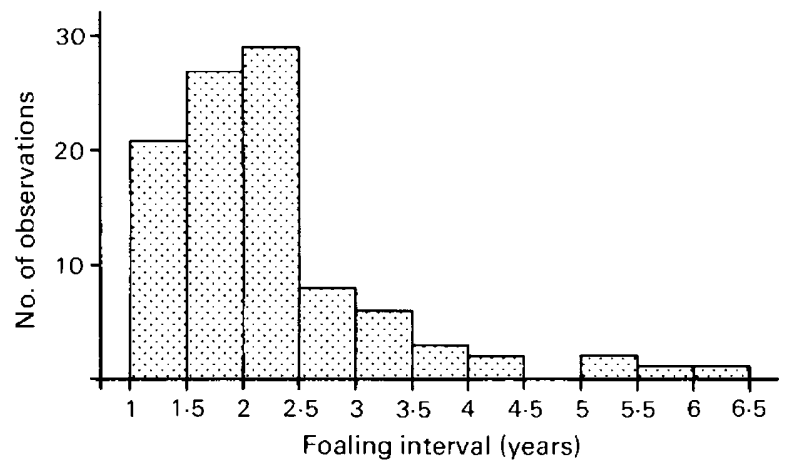

Text-fig. 2. The foaling intervals of 49 Cape mountain zebra mares ( 100 foals born) in the Mountain Zebra National Park (median 25 months).

Table 1. Foaling record of 82 free-ranging Cape mountain zebra mares observed between 1 and 13 years

\begin{tabular}{|c|c|c|c|c|c|c|c|c|c|}
\hline \multicolumn{2}{|c|}{ Mares } & \multirow{2}{*}{\multicolumn{8}{|c|}{ Number of foals born/mare }} \\
\hline No of & No of & & & & & & & & \\
\hline years observed & mares observed & 0 & 1 & 2 & 3 & 4 & 5 & 6 & 7 \\
\hline 1 & 8 & 7 & 1 & - & - & - & - & - & - \\
\hline 2 & 8 & 4 & 3 & 1 & - & - & - & - & - \\
\hline 3 & 4 & 1 & 3 & - & - & - & - & - & - \\
\hline 4 & 4 & 1 & 1 & 2 & - & - & - & - & - \\
\hline 5 & 1 & - & 1 & - & - & - & - & - & - \\
\hline 6 & 8 & - & 2 & 4 & 1 & 1 & - & - & - \\
\hline 7 & 9 & - & 2 & 1 & 5 & 1 & - & - & - \\
\hline 8 & 11 & -. & 1 & 4 & 5 & 1 & - & - & - \\
\hline 9 & 9 & - & 4 & 1 & 3 & 1 & - & - & 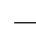 \\
\hline 10 & 4 & - & - & 2 & 2 & - & - & - & - \\
\hline 11 & 11 & - & 1 & $\ldots$ & 3 & 5 & 1 & 1 & - \\
\hline 12 & 4 & - & - & - & - & 3 & - & 1 & - \\
\hline 13 & 1 & - & - & - & - & - & - & - & 1 \\
\hline
\end{tabular}

The reproductive records of 82 mares observed between 1 and 13 years are shown in Table 1 . In a total of 559 mare years 178 foals were born, giving 0.32 foal/mare/year (or a foaling rate of $32 \%$ ).

\section{Foaling season}

The births of 306 Cape mountain zebra foals were recorded during the 30 years from 1 July 1952 to 30 June 1982 . The monthly distribution of births and mean monthly precipitation are shown in Text-fig. 3. Over the 30-year period the same number of foals (153) was born during the two 6month periods (July-December and January-June) respectively. As the gestation period is taken to be about 1 year, Text-fig. 3 also illustrates the monthly distribution of conceptions. Significantly more foals were born during summer than in winter $\left(213 v s 93 ; \chi^{2}=47.0588 ; \mathrm{df}=1 ; P<0.01\right)$. The foaling peak therefore corresponds with the rainy season. The 6-month period with the highest mean precipitation is November-April, with $74.3 \%$ of the annual total : 210 foals were born during 


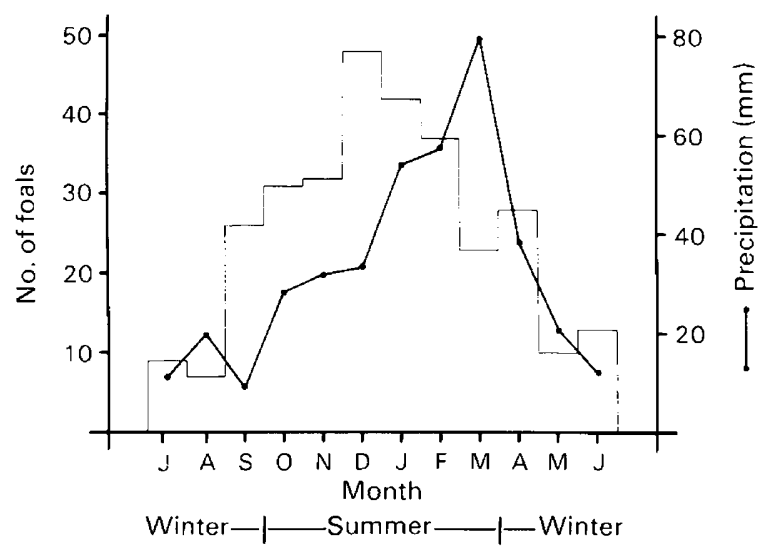

Text-fig. 3. Monthly distribution of the births of 306 Cape mountain zebra foals (histogram) and the mean monthly precipitation recorded in the Mountain Zebra National Park (line).

these months. The 6-month period with the greatest number of foals was September-February, with 215 foals born.

\section{Precipitation and the foaling season}

The same number of foals was born early or late during the 30 foaling seasons considered. During some years the majority of foals was born early while in others the majority was born late. The number of foals born during the first and second halves of the foaling seasons July 1966-June 1982 and the precipitation recorded during the first half of the previous season are shown in Table 2. A one-tailed test of hypergeometric distribution in a $2 \times 2$ contingency table based on these data

Table 2. The precipitation recorded in the Mountain Zebra National Park during the first half of the foaling season and the number of Cape mountain zebra foals born during the next foaling season

\begin{tabular}{|c|c|c|c|c|c|}
\hline \multirow[b]{2}{*}{ Year } & \multirow{2}{*}{$\begin{array}{l}\text { Precipitation } \\
\text { (July-Dec.) } \\
\text { (mm) }\end{array}$} & \multirow[b]{2}{*}{ Dry spring* } & \multicolumn{2}{|c|}{ Next season's foal crop $\dagger$} & \multirow[b]{2}{*}{ Foals late } \\
\hline & & & $\begin{array}{c}\text { Born } \\
\text { July-Dec. }\end{array}$ & $\begin{array}{c}\text { Born } \\
\text { Jan.-June }\end{array}$ & \\
\hline 1965 & 166.9 & No & 10 & 3 & No \\
\hline 1966 & $35 \cdot 5$ & Yes & 5 & 6 & Yes \\
\hline 1967 & 67.0 & Yes & 10 & 9 & No \\
\hline 1968 & 134.0 & No & 15 & 3 & No \\
\hline 1969 & $95 \cdot 7$ & Yes & 9 & 11 & Yes \\
\hline 1970 & 192.5 & No & 14 & 11 & No \\
\hline 1971 & $251 \cdot 5$ & No & 5 & 4 & No \\
\hline 1972 & $35 \cdot 5$ & Yes & 3 & 15 & Yes \\
\hline 1973 & 97.5 & Yes & 9 & 7 & No \\
\hline 1974 & 161.0 & No & 8 & 5 & No \\
\hline 1975 & 190.9 & No & 8 & 4 & No \\
\hline 1976 & 143.5 & No & 14 & 10 & No \\
\hline 1977 & 168.5 & No & 9 & 1 & No \\
\hline 1978 & 105.0 & Yes & 9 & 12 & Yes \\
\hline 1979 & 187.0 & No & 4 & 9 & Yes \\
\hline 1980 & $81 \cdot 5$ & Yes & 0 & 14 & Yes \\
\hline
\end{tabular}

* Precipitation during July-December less than the mean of $130.5 \mathrm{~mm}$.

$†$ The 12-month period starting on 1 July of the following year.

$\$$ Fewer than half of the season's foal crop born during the first 6 months (July-December). 
was carried out. Low precipitation during the first half of the foaling season was associated with the majority of conceptions occurring during the second half of the season, while high precipitation was associated with a majority of early conceptions $(0.95 \leqslant P \leqslant 0.98)$.

No correlation between total precipitation during the season that conception took place and the size of the subsequent foal crop could be demonstrated. The size of the foal crop varied from 9 to 25 , with no evident pattern. Good foal crops were often followed by small ones, irrespective of the rainfall.

\section{Discussion}

The minimum age at first foaling (38 months) agrees with that reported for other equids (King, 1965; Klingel, 1969; Joubert, 1974; Smuts, 1976). Cape mountain zebra fillies leave their maternal herds at a mean age of 21.85 months and are often in oestrus at the time (Penzhorn, 1984a). Most New Forest pony mares first foal at 4 or 5 years or even later (Pollock, no date). In the Kruger National Park all 3.5-year-old plains zebra ( $E$. burchelli) mares in the sample were found to have ovulated, with a conception rate of $73.3 \%$ (Smuts, 1976). The mean age at first foaling in that population would probably be 4-5 years. The MZNP figure compares favourably with that for other wild and feral equid populations.

The reproductive lifespan of the MZNP mares agrees with that reported for other equids (King, 1965; Veselovsky \& Volf, 1965). A captive Hartmann zebra mare foaled when 24 years old (Penzhorn, 1975). No evidence of reproductive senescence was found in free-living plains zebra mares (Smuts, 1976). Fertility of domestic horse mares gradually declines after 13-14 years of age (Hughes, 1980), but foaling rates of younger and older Cape mountain zebras are similar.

The median foaling interval of MZNP mares is similar to that reported for Hartmann zebra mares (Shortridge, 1934). The mean foaling interval of 6 captive Hartmann zebra mares was 544 days ( $\sim 18$ months) (Penzhorn, 1975). Only MZNP mares that foaled at least twice were included in these data: 13 mares were not recorded as foaling and 19 foaled once only (Table 1). The reproductive success of individual mares varied markedly: one mare produced 7 foals in 13 years, while another was recorded as foaling once only in 11 years. One mare had 4 foals in 7 years, followed by 5 barren years until her death at $\geqslant 24$ years.

The annual foaling rate of feral ponies on the northern part of Assateague Island National Seashore, Maryland, U.S.A. was $61.4 \%$. On the southern part of the island, where mares do not have to suckle the previous summer's foals through the winter, a 4-year mean foaling rate during the same period was $74.4 \%$ (Keiper, 1979). Frequency of suckling by Cape mountain zebra foals decreases to $1-3$ bouts per day at 10 months of age and weaning often takes place at this time (Penzhorn, 1984a). This relieves the lactational stress on the mare. In the Ngorongoro Crater, Tanzania, 120 plains zebra mares observed over 3 years produced 0.51 foal/mare/year (calculated from data given by Klingel, 1969). This figure represents surviving foals only. There are numerous predators in the Crater (Kruuk, 1972) and some of the newborn foals probably fell prey to these before they were recorded. There are no large predators in the MZNP.

Feral domestic horse stallions displacing herd stallions force the mares to submit to copulation, leading to the loss of pregnancies of $<180$ days (Berger, 1983). The social system of mountain zebras is the same as that of feral horses (Penzhorn, 1984a) and a similar situation may be present in mountain zebras, which would adversely affect the foaling rate. Six mountain zebra herd stallions were displaced during a 3-year observation period. None of the 17 mares in the 6 herds foaled within 12 months of the take-over by the new stallion. With an annual foaling rate of $32 \%, 5-6$ foals could have been expected from these mares. There were 21 breeding herds in the population at that time. The 2 herd stallions displaced each year affected about $10 \%$ of the mare population.

The effect of inbreeding in domestic livestock is generally detrimental, with fertility and viability of the offspring being two of the traits affected (Warwick \& Legates, 1979). The MZNP population is derived from a small number of individuals; a single stallion from a different 
population was added in the early 1970s. The reduction in heterozygosity per generation in 1965

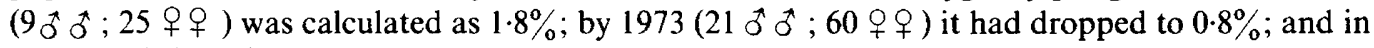
1984 (35 $ぇ ; 78$ 우 ) it was $0.05 \%$ (Wright's formula quoted by Warwick \& Legates, 1979). This is rather low and inbreeding is probably of minor importance at this stage.

Infertile or subfertile herd stallions would obviously influence the foaling rate. Semen evaluation has not been done on any of the MZNP stallions, but herd records have not shown any stallions to be infertile.

Sufficient precipitation during the period that daylength is increasing will result in green, sprouting vegetation. After the dry winter the mares will therefore be on a rising plane of nutrition. Lean domestic horse mares that are gaining weight at the beginning of the breeding season generally have the greatest reproductive efficiency (Schryver \& Hintz, 1980) and the same probably applies to other equids. Poor or erratic rainfall during the months of peak mating activity (November-February) may result in low conception rates among plains zebras in the Kruger National Park (Smuts, 1976).

The reproductive success of the MZNP mares seems very low compared to that of the two other equid populations cited. Nevertheless, the MZNP population increased from 55 to 230 in 20 years, at which level it is being maintained by the capture and translocation of surplus animals. The relatively poor grazing and harsh climate of the MZNP could adversely influence the foaling rate. During dry periods, apart from nutritional stress, the additional effect of lactation probably prevents Cape mountain zebra mares from cycling or conceiving and may also lead to resorption or abortion of the fetus. Embryonic resorption tends to occur 25-30 days after ovulation in domestic horse mares on a poor nutritional plane (van Niekerk, 1965). There are also indications that ecological factors are the most important causes of mortality in the MZNP population (Penzhorn, 1984b). Cape mountain zebras have been shown to be selective climax grazers feeding at a fairly high level off the ground (Grobler: 1983). Various antelope species inhabit the MZNP (Penzhorn, $1982 \mathrm{~b}$ ) and if low level grazing antelopes are allowed to increase to the extent that mean grass height is kept below that of mean zebra feeding height, it would be detrimental to the zebra population. Management policy should therefore be aimed at reducing interspecific competition for grazing between the zebras and other herbivores which inhabit the MZNP.

Portions of this report are based on a D.Sc. (Wildlife Management) dissertation submitted to the University of Pretoria. I acknowledge the contribution by my supervisors, Professor J. du P. Bothma and Dr G. de Graaff, and thank the National Parks Board, my employers at the time. Before 1971 records were maintained by the MZNP Wardens. After 1976 the records were kept by Dr A. J. Hall-Martin and Dr J. H. Grobler, whom I thank for permission to include their data in this analysis. I also thank Dr Frederick A. Ulmer (Philadelphia Zoological Garden), Dr Arnd Wünschmann (Münchner Tierpark Hellabrun) and Professor Dr Heinz-Georg Klös (Berlin Zoological Gardens) for information on the breeding of Hartmann zebras in captivity; Mr S. E. Piper and Mr A. G. Pols for advice on the statistical analyses; and Mrs M. R. Hattingh for drawing the text-figures.

\section{References}

Belonje, C.W.A. (1956) The influence of running a stallion with non-pregnant thoroughbred mares. $J . S$. Afr. vet. med. Ass. 27, 57-60.

Berger, J. (1983) Induced abortion and social factors in wild horses. Nature, Lond. 303, 59-61.

Bristol, F. (1982) Breeding behaviour of a stallion at pasture with 20 mares in synchronised oestrus. $J$. Reprod. Fert., Suppl. 32, 71-77.

Grobler, J.H. (1983) Feeding habits of the Cape mountain zebra Equus zebra zebra Linn. 1758. Koedoe 26, 159-168.
Hammond, J., Mason, I.L. \& Robinson, T.J. (1971) Hammond's Farm Animals. Edward Arnold, London.

Hughes, J.P. (1980) Clinical examination and abnormalities in the mare. In Current Therapy in Theriogeno$\log y$, pp. 706-721. Ed. D. A. Morrow. W. B. Saunders, Philadelphia.

Joubert, E. (1974) Notes on reproduction in Hartmann zebra Equus zebra hartmannae in South West Africa. Madoqua Ser. I 8, 31-35.

Keiper, R.R. (1979) Population dynamics of feral ponies. In Proceedings of Symposium on Ecology and Behavior 
of Wild and Feral Equids, pp. 175-183. Ed. R. H. Denniston. University of Wyoming, Laramie.

King, J.M. (1965) A field guide to the reproduction of Grant's and Grevy's zebra. E. Afr. Wildl. J. 3, 99117.

Klingel, H. (1969) Reproduction in the plains zebra, Equus burchelli boehmi: behaviour and ecological factors. J. Reprod. Fert., Suppl. 6, 339-345.

Kruuk, H. (1972) The Spotted Hyena. University of Chicago Press, Chicago.

Penzhorn, B.L. (1975) Behaviour and population ecology of the Cape mountain zebra Equus zebra zebra Linn., 1758 in the Mountain Zebra National Park. D.Sc. (Wildlife Management) dissertation, University of Pretoria.

Penzhorn, B.L. (1982a) Age determination in Cape mountain zebras Equus zebra zebra in the Mountain Zebra National Park. Koedoe 25, 89-102.

Penzhorn, B.L. (1982b) Habitat selection by Cape mountain zebras in the Mountain Zebra National Park. S. Afr. J. Wildl. Res. 12, 48-54.

Penzhorn, B.L. (1984a) A long-term study of social organisation and behaviour of Cape mountain zebras Equus zebra zebra. Z. Tierpsychol. 64, 97-146.

Penzhorn, B.L. (1984b) Observations on mortality of free-ranging Cape mountain zebras Equus zebra zebra. S. Afr. J. Wildl. Res. 14, 89-90.
Pollock, J.I. (no date) Behavioural ecology and body condition changes in New Forest ponies. RSPCA Publications, No. 6.

Rowlands, I.W. (1981) Perspectives in perissodactyls. Equine vet. J. 13, 85-87.

Schryver, H.F. \& Hintz, H.F. (1980) Nutrition and reproduction in the horse. In Current Therapy in Theriogenology, pp. 768-777. Ed. D. A. Morrow. W. B. Saunders, Philadelphia.

Shortridge, G.C. (1934) The Mammals of South West Africa, Vol. 1. Heinemann, London.

Smuts, G.L. (1976) Reproduction in the zebra mare Equus burchelli antiquorum from the Kruger National Park. Koedoe 19, 89-132.

van Niekerk, C.H. (1965) Early embryonic resorption in mares. J. S. Afr. vet. med. Ass. 36, 61-69.

van Rensburg, S.W.J. \& van Heerden, J.S. (1953) Infertility in mares caused by ovarian dysfunction. Onderstepoort J. vet. Res. 26, 285-313.

Veselovsky, Z. \& Volf, J. (1965) Breeding and care of rare Asian equids at Prague Zoo. Int. Zoo Yb. 5, 28-37.

Warwick, E.J. \& Legates, J.E. (1979) Breeding and Improtement of Farm Animals, 7th edn. McGraw. Hill, New York.

Received 9 March 1984 